\title{
Effect of Calcium Ion on Triiodothyronine Binding to Kidney Outer Mitochondrial Membrane in vitro
}

\author{
Kiyoshi HASHIZUME, Kazuo ICHIKAWA and Mutsuhiro KOBAYASHI
}

Department of Gerontology, Endocrinology and Metabolism, Shinshu University School of Medicine, Matsumoto 390

\begin{abstract}
The effect of calcium ion on $3,5,3^{\prime}$-triiodothyronine $\left(\mathrm{T}_{3}\right)$ binding to rat kidney outer mitochondrial membranes was examined in vitro. The outer mitochondrial membranes were prepared by using a discontinuous sucrose density gradient centrifugation. The membrane fraction, which is enriched with monoamine oxidase activity, contained specific binding sites for $T_{3}$. Scatchard analysis of $T_{3}$ binding to outer mitochondrial membranes gave an association constant $(\mathrm{Ka})$ of $0.53 \times 10^{10} \mathrm{M}^{-1}$. The binding of $\left[{ }^{125} \mathrm{I}\right]-\mathrm{T}_{3}$ to the membranes was inhibited by the addition of $\mathrm{CaCl}_{2}\left(0.25 \times 10^{-4}-2.5 \times 10^{-3} \mathrm{M}\right)$. $50 \%$ inhibition was obtained by $0.75 \times 10^{-4} \mathrm{M} \mathrm{CaCl}_{2}$ in the presence of $0.1 \mathrm{mM}$ EGTA. When outer mitochondrial membranes were solubilized with Triton $\mathrm{X}-100$, four main $\mathrm{T}_{3}$ binding activities were isolated by a gel filtration study. On the other hand, the binding of $\left[{ }^{125} \mathrm{I}\right]-\mathrm{T}_{3}$ to the solubilized $\mathrm{T}_{3}$ receptors derived from outer mitochondrial membranes was not strongly inhibited by calcium.

When outer mitochondrial membranes were preincubated in the presence of $1 \mathrm{mM}$ calcium, the number of $\mathrm{T}_{3}$ binding sites in the membranes was decreased, and this was associated with an increase in the number of $T_{3}$ binding sites in the supernatants of the incubation mixture. Scatchard analysis showed that the number of $T_{3}$ binding sites in the membranes is decreased by calcium ion without any change in the association constant. In studies with gel filtration of receptors which are released by $\mathrm{Ca}^{2+}$ from outer mitochondrial membranes, three main $\mathrm{T}_{3}$ binding activities were isolated. $\mathrm{Mg}^{2+}, \mathrm{Mn}^{2+}, \mathrm{Zn}^{2+}$ and $\mathrm{Cu}^{2+}$ did not affect $\mathrm{T}_{3}$ binding to outer mitochondrial membranes.

The results indicate that calcium ion regulates $T_{3}$ binding to the outer mitochondrial membrane through the release of $\mathrm{T}_{3}$ receptors from the membranes.
\end{abstract}

It is well established that mitochondria play an important role in storing large amounts of calcium. The calcium concentration in the extramitochondrial space is strictly regulated by the mitochondrial cal-

Received February 6, 1984 cium transport system (Carafoli and Cromton, 1978). Several hormones modify the calcium transport system in mitochondria (Rasmussen and Gustin, 1978). Thyroid hormone stimulates calcium release from mitochondria (Shears and Bronk, 1981, Harris, 1979). The mechanism of the stimula- 
tion of calcium release is known to be a result of thyroid hormone-induced augmentation of mitochondrial permeability to calcium (Harris, 1979, Hullert et al., 1976, Statav et al., 1976). The changes in the calcium concentration in the extramitochondrial space may induce the modification of many aspects of metabolism in this space. Calcium-dependent proteinase activity (Guroff, 1964, Murachi et al., 1980, Murachi et al., 1981), calcium binding protein (calmodulin), and several calcium-requiring enzyme activities may be modified by the changes in calcium concentration. An increase in the calcium concentration in this space, which is induced by thyroid hormone, may also induce modifications of these enzymes.

We have previously reported that outer and inner mitocondrial membranes have specific binding sites for $3,5,3^{\prime}$-triiodothyronine $\left(\mathrm{T}_{3}\right)$ (Hashizume \& Ichikawa, 1982). And we suggested that the binding is regulated by calcium ion in vitro. However, the mechanism of inhibition of $\mathrm{T}_{3}$ binding to the membranes is not yet known. An increase in calcium concentration may activate the calcium-activated proteinase activity and may induce release of $\mathrm{T}_{3}$ receptors, or inactivation of receptors.

In the present study, we examined whether or not calcium ion has a regulatory effect on $T_{3}$ binding to outer mitochondrial membranes in vitro. Our results indicate that calcium ion decreases the number of $\mathrm{T}_{3}$ binding sites in outer mitochondrial membranes, and that is accompanied by the release of $T_{3}$ receptors from outer mitochondrial membranes.

\section{Materials and Methods}

\section{Preparation of mitochondrial membranes}

Mitochondria were prepared from male Wistar rat kidney by the method of Mela and Seits (1979) with minor modifications. All produceres were done in the presence of $1.0 \mathrm{mM}$ EGTA and $1.0 \mathrm{mM}$ dithiothreitol (DTT) (Sigma
Chemical Co.). The outer and inner membranes were prepared by the method of Comte and Gautheron (1979) by using discontinuous sucrose density gradient centrifugation. As a maker enzyme located on the outer mitochondrial membranes, monoamine oxidase (MAO) activity was measured by the method of Wurtman and Axelerod (1963) using $\left[{ }^{14} \mathrm{C}\right]$-tryptamine bisuccinate (SA ; $30 \mathrm{mCi} / \mathrm{mmol}$ ) (New England Nuclear, Boston, MA, U.S.A) as substrate (Ichikawa et al. 1982).

\section{Solubilization of mitochondrial membranes}

Solubilization of mitochondrial membranes was done as follows. The membrane fraction (5-10 $\mathrm{mg}$ protein) was incubated in $50 \mathrm{mM}$ sodium phosphate buffer $\mathrm{pH}$ 7.5, containing $0.25 \%$ Triton $\mathrm{X}-100,1.0 \mathrm{mM}$ EGTA, $1 \mathrm{mM}$ DTT and $5 \%$ glycerol for $1 \mathrm{hr}$ at $4^{\circ} \mathrm{C}$. After incubation, the mixture was centrifuged at $105,000 \times g$ for $1 \mathrm{hr}$ at $0^{\circ} \mathrm{C}$. The supernatant was used as a fraction contained soluble $T_{3}$ receptors, and the pellet suspended with the same volume of the buffer was used as the residual membrane fraction. To remove Triton $\mathrm{X}-100$ from these fractions each fraction was passed through a small column of Amberlite XAD-2 (Sigma) which had been equilibrated with the same buffer that did not contain Triton $\mathrm{X}-100$.

\section{Receptor release from mitochondrial membranes}

The effect of $\mathrm{Ca}^{2+}$ on the release of $\mathrm{T}_{3}$ receptors from outer mitochondrial membrane was examined as follows. The membrane fraction (5-10 mg of protein) was incubated with $\mathrm{CaCl}_{2}$

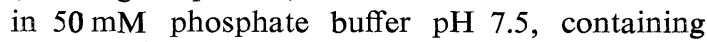
$1.0 \mathrm{mM}$ DTT for $1 \mathrm{hr}$ at $34^{\circ} \mathrm{C}$. In the control, $\mathrm{CaCl}_{2}$ was omitted and $1.0 \mathrm{mM}$ EGTA was added to the incubation medium. After incubation the mixture was centrifuged at $105,000 \times g$ for $1 \mathrm{hr}$ at $0^{\circ} \mathrm{C}$. The precipitate was suspended with the same volume of the buffer which did not contain $\mathrm{CaCl}_{2}$ and was used as the residual membrane fraction. The supernatant contained released $\mathrm{T}_{3}$ receptors. Both preparations were dialyzed against $50 \mathrm{mM}$ phosphate buffer $\mathrm{pH} 7.5$, containing $1.0 \mathrm{mM}$ EGTA and $1.0 \mathrm{mM}$ DTT overnight, and the $T_{3}$ binding activity in these fractions was measured.

\section{$T_{3}$ binding assay}

Binding assay was carried out by the method of Sterling and Milch (1975). The reaction mixture contained $0.1 \mathrm{mM}$ EGTA, $1.0 \mathrm{mM}$ DTT and 
a trace amount of $\left[{ }^{125} \mathrm{I}\right]-\mathrm{T}_{3}(10,000-20,000 \mathrm{cpm})$ (SA ; $150 \mu \mathrm{Ci} / \mu \mathrm{g}$ ) (New England Nuclear) in a total volume of $350 \mu \mathrm{l}$ of $50 \mathrm{mM}$ sodium phosphate buffer $\mathrm{pH}$ 7.5. The reaction was started by adding $100 \mu \mathrm{l}$ aliquotes of either mitochondrial membrane fraction or soluble (or released) receptor fraction, and incubation was performed in the presence or absence of unlabeled $\mathrm{T}_{3}\left(10^{-6} \mathrm{M}\right)$ (Sigma) for $1 \mathrm{hr}$ at $30^{\circ} \mathrm{C}$. The reaction was terminated by cooling the mixture in an ice bath. In the case of $T_{3}$ binding to the membranes, the membrane-bound hormone was separated by centrifugation of the incubation mixture at $105,000 \times g$ for $30 \mathrm{~min}$. at $0^{\circ} \mathrm{C}$. In the case of $\mathrm{T}_{3}$ binding to the solubilized or released $\mathrm{T}_{3}$ receptors, the free hormone was separated from the bound hormone with Dextran-coated charcoal (Norit "A" Dextran $50,000-90,000$ molecular weight. both $10 \mathrm{~g} / 1)$. Specific binding of $\left[{ }^{125} \mathrm{I}\right]-\mathrm{T}_{3}$ was caluculated by subtraction of the $\left[{ }^{125} \mathrm{I}\right]-\mathrm{T}_{3}$ bound in the presence of $10^{-6} \mathrm{M}$ of unlabeled $\mathrm{T}_{3}$ (Hashizume and Ichikawa, 1982).

Gel filtration of $T_{3}$ receptors was carried out on a column of Sephadex G-100 (Pharmacia), $60 \times 2 \mathrm{~cm}$, and the receptors were eluted with $50 \mathrm{mM}$ phosphate buffer $\mathrm{pH} 7.5$, containing $0.1 \mathrm{mM}$ EGTA, $1.0 \mathrm{mM}$ DTT and $5 \%$ glycerol. The protein concentration was measured by the method of Lowry et al. (1951) using bovine serum albumin (BSA) (Sigma) as a standard.

\section{Results}

Localization of $T_{3}$ receptors in rat kidney mitochondrial membranes

As we have previously demonstrated, the MAO-enriched fraction which is considered to be the outer mitochondrial membrane fraction contained high $\mathrm{T}_{3}$ binding activity (Hashizume and Ichikawa, 1982). Cytosol, microsomal and inner mitochondrial membrane fractions also contained $\mathrm{T}_{3}$ binding activity, but specific activity for $T_{3}$ binding to these fractions was lower than that of outer mitochondrial membrane fraction (Table 1). [ $\left.{ }^{125} \mathrm{I}\right]-\mathrm{T}_{3}$ binding to outer mitochondrial membrane was displaced by unlabeled $\mathrm{T}_{3}$ in a concentration dependent manner, and $50 \%$ displacement was obtained by $0.7 \times 10^{-9} \mathrm{M}$ of unlabeled $\mathrm{T}_{3}$. The association constant $(\mathrm{Ka})$ of binding to outer mitochondrial membranes was $0.53 \times 10^{10} \mathrm{M}^{-1}$ (Hashizume and Ichikawa, 1982).

The effect of calcium ion on $T_{3}$ binding to outer mitochondrial membranes

$\left[{ }^{125} \mathrm{I}\right]-\mathrm{T}_{3}$ binding to outer mitochondrial membranes was reduced by the addition of calcium ion in vitro. Fig. 1 shows a typical concentration curve for the inhibition of binding of $\left[{ }^{125} \mathrm{I}\right]-\mathrm{T}_{3}$ to outer mitochondrial

Table 1. Localization of $T_{3}$ binding activities in rat kidney mitochondrial membranes.

\begin{tabular}{lcc}
\hline Fraction & $\begin{array}{c}{\left[{ }^{125} \mathrm{I}\right]-\mathrm{T}_{3} \text { binding }} \\
(\mathrm{cpm} / 100 \mu \mathrm{g} \text { of protein })\end{array}$ & $\begin{array}{c}\text { MAO activity } \\
\left.\left({ }^{14} \mathrm{C}\right]-\text { tryptamine oxidized }\right) \\
(\mathrm{nmoles} / \mu \mathrm{g} \text { protein } \cdot 20 \mathrm{~min})\end{array}$ \\
\hline Exp. 1 & 750 & 2.62 \\
Cytosol & 980 & 1.54 \\
Microsomal & 2180 & 1.94 \\
Inner mitochondrial membrane & 3620 & 28.44 \\
Outer mitochondrial membrane & & \\
Exp. 2 & 840 & 2.21 \\
Cytosol & 689 & 1.04 \\
Microsomal & 2620 & 2.01 \\
Inner mitochondrial membrane & 4400 & 29.36 \\
Outer mitochondrial membrane &
\end{tabular}

Each value is the mean of triplicate determinations. 


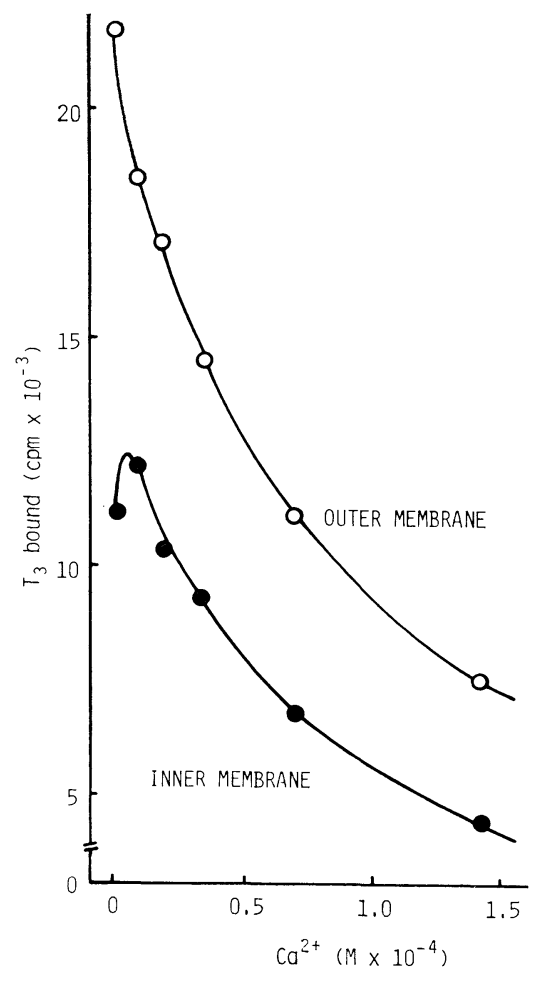

Fig. 1. Effect of calcium ion on $T_{3}$ binding to inner or outer mitochondrial membranes.

Mitochondrial menbranes were prepared from rat kidney mitochondria as mentioned in the Materials and Methods. The binding assay was carried out in the presence of $100 \mu \mathrm{M}$ EGTA and various concentrations of $\mathrm{Ca}^{2+}$. $10^{5} \mathrm{cpm}$ of $\left[{ }^{125} \mathrm{I}\right]-\mathrm{T}_{3}$ were added in each reaction. The specific binding of $T_{3}$ is shown. Each result is the mean of triplicate determinations.

Table 2. Effect of cations on $\mathrm{T}_{3}$ binding to outer mitochondrial membranes.

\begin{tabular}{lrrr}
\hline & \multicolumn{3}{c}{$\%$ of binding in the absence of cation } \\
\cline { 2 - 4 } & \multicolumn{3}{c}{ Concentration $\left(\times 10^{-4} \mathrm{M}\right)$} \\
\cline { 2 - 4 } Cations & 0.5 & 1.0 & 2.5 \\
\hline $\mathrm{Ca}^{2+}$ & 41.6 & 29.7 & 20.8 \\
$\mathrm{Mg}^{2+}$ & 88.1 & 78.7 & 72.8 \\
$\mathrm{Mn}^{2+}$ & 88.6 & 72.1 & 66.8 \\
$\mathrm{Zn}^{2+}$ & 112.1 & 126.6 & 72.6 \\
$\mathrm{Cu}^{2+}$ & 149.2 & 97.3 & 57.7 \\
\hline
\end{tabular}

Each value is the mean of triplicate determinations.
Table 3. $\left[{ }^{125} \mathrm{I}\right]-\mathrm{T}_{3}$ binding to solubilized fraction of outer mitochondrial membranes.

\begin{tabular}{lr}
\hline Fraction & $\begin{array}{c}{\left[{ }^{125} \mathrm{I}\right]-\mathrm{T}_{3} \text { binding }} \\
(\mathrm{cpm} / 100 \mu \mathrm{g} \text { of protein })\end{array}$ \\
\hline $\begin{array}{l}\text { Outer membrane } \\
\text { Outer membrane before }\end{array}$ & \\
solubilization & 2830 \\
$\quad$ Residual outer membrane & 130 \\
Soluble fraction & 26860 \\
\hline
\end{tabular}

Residual outer membrane and soluble fraction were prepared by using Triton X-100 as mentioned in the Materials and Methods. Soluble fraction indicates the $105,000 \times g$ supernatant after treatment of the outer membrane with Triton $\mathrm{X}-100$. Each value is the mean of triplicate determinations.

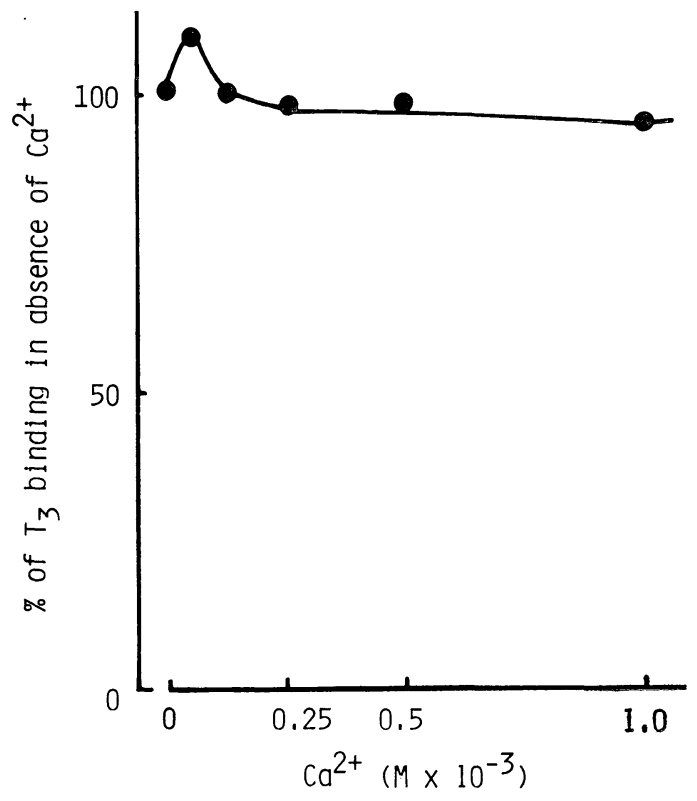

Fig. 2. Effect of calcium ion on $\mathrm{T}_{3}$ binding to solubilized fraction prepared from outer mitochondrial membranes.

Binding reaction contained various concentrations of $\mathrm{Ca}^{2+}$ and solubilized protein $(100 \mu \mathrm{g} /$ tube $)$. The reactions were performed in the presence or absence of $10^{-6} \mathrm{M}$ unlabeled $\mathrm{T}_{3}$. The specific binding of $\mathrm{T}_{3}$ was illustrated. Each value is the mean of triplicate determinations. 
membrane preparation by calcium ion. Calcium ion in the concentration from $0.25 \times$ $10^{-4}$ to $2.5 \times 10^{-3} \mathrm{M}$ strongly inhibited the $\left[{ }^{125} \mathrm{I}\right]-\mathrm{T}_{3}$ binding. The binding of $\left[{ }^{125} \mathrm{I}\right]-\mathrm{T}_{3}$ to inner membrane was also inhibited by calcium ion. Other divalent cations, such as $\mathrm{Mg}^{2+}, \mathrm{Mn}^{2+}, \mathrm{Zn}^{2+}$ and $\mathrm{Cu}^{2+}$, in their lower concentrations, did not inhibit $\left[{ }^{125} \mathrm{I}\right]-\mathrm{T}_{3}$ binding to outer mitochondrial membranes. Higher concentrations of these ions, however, inhibited $\left[{ }^{125} \mathrm{I}\right]-\mathrm{T}_{3}$ binding to the membrane (Table 2).

The effect of calcium ion on $T_{3}$ binding to soluble $T_{3}$ receptors prepared from outer mitochondrial membranes

Soluble fraction of Triton X-100-treated mitochondrial membranes contained binding sites for $T_{3}$. Specific activity for $T_{3}$ binding was increased 9.4 fold by solubilization (Table 3). Calcium ion was tested for its ability to inhibit $\left[{ }^{125} \mathrm{I}\right]-\mathrm{T}_{3}$ binding to the receptors in this fraction. Even $1 \mathrm{mM}$ calcium ion did not inhibit $\mathrm{T}_{3}$ binding to solubilized receptors (Fig. 2). In studies with gel filtration of solubilized receptors, four main $\mathrm{T}_{3}$ binding activities were isolated (Hashizume and Ichikawa, 1982). Calcium ion was again tested for its ability to inhibit $\mathrm{T}_{3}$ binding to each receptor. Calcium ion slightly inhibited $\left[{ }^{125} \mathrm{I}\right]-\mathrm{T}_{3}$ binding to receptors present in $\mathrm{B}$ fraction in Fig. 3. When $\mathrm{C}$ and $\mathrm{D}$ fractions, obtained by the gel filtration study shown in Fig. 3, were used as receptor fractions, calcium ion did not inhibit $\left[{ }^{125} \mathrm{I}\right]-\mathrm{T}_{3}$ binding to these receptors. Calcium ion, in these cases, enhanced binding of $\mathrm{T}_{3}$ to these receptors. Binding of $T_{3}$ to receptor $C$ was enhanced by lower calcium concentrations $(0.125 \times$ $\left.10^{-3}-0.25 \times 10^{-3} \mathrm{M}\right)$ and that to fraction $\mathrm{D}$ was enhanced by higher concentrations of calcium ion (more than $0.5 \times 10^{-3} \mathrm{M}$ ), as shown in Fig. 4.

\section{$\mathrm{Ca}^{2+}$-induced $\mathrm{T}_{3}$ receptor release from outer mitochondrial membranes}

The above results suggest that $\mathrm{Ca}^{2+}$ does not directly inhibit $T_{3}$ binding to receptor molecules and that $\mathrm{Ca}^{2+}$ may interact with outer mitochondrial membrane and may result in a decrease in binding activity in the membrane. In order to investigate the mechanism of $\mathrm{Ca}^{2+}$-induced reduction of $\mathrm{T}_{3}$ binding activity in the membrane, $\mathrm{Ca}^{2+}$ pretreated membranes were tested for their

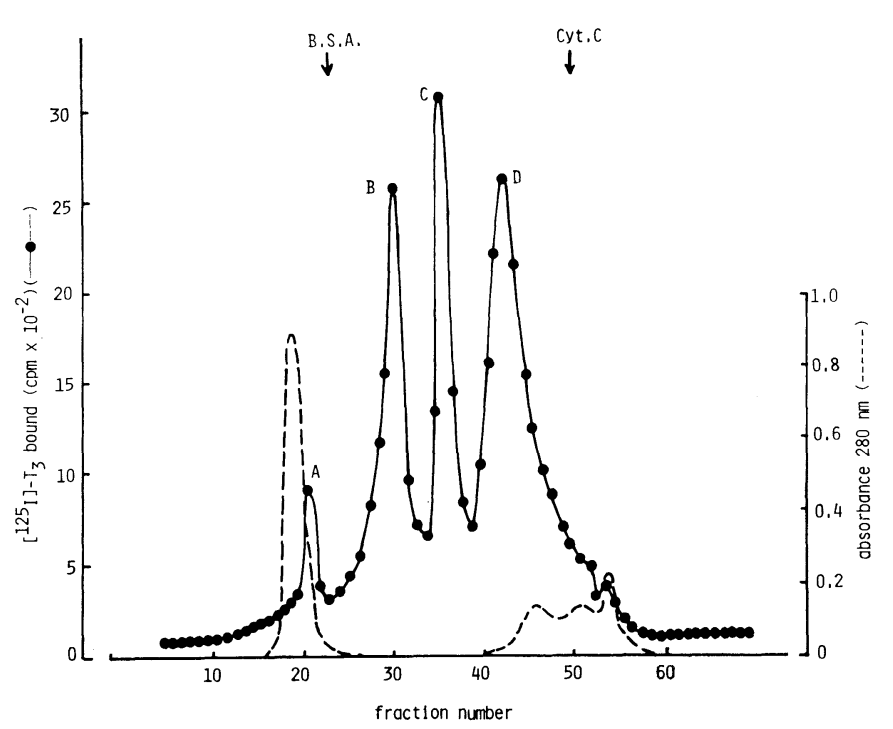

Fig. 3. Gel chromatography profile of soluble $T_{3}$ receptors.

The outer mitochondrial membranes were solubilized by $0.25 \%$ Triton $\mathrm{X}-100$. Solubilized membrane fraction was applied to a Sephadex G-100 column and the receptors were eluted. The binding activity in each fraction was assayed in the absence or presence of unlabeled $\mathrm{T}_{3}$. The elution positions of BSA and cytochrome $c$ (Cyt. C) are indicated. 
ability to bind $T_{3}$.

During the incubation of outer mitochondrial membranes with $1 \mathrm{mM} \mathrm{Ca}^{2+}$, the binding activity for $T_{3}$ in the membranes decreased. $\mathrm{T}_{3}$ binding activity in the supernatant of the incubation mixture of the membranes with calcium ion, on the contrary, was increased in a time dependent manner (Fig. 5). Fig. 6 show the $\mathrm{T}_{3}$ binding activity in the $\mathrm{Ca}^{2+}$-pretreated outer mitochondrial membranes and that in the supernatant of the incubation mixture. Scatchard analysis indicated a decrease in the number of $\mathrm{T}_{3}$ binding sites on outer mito-

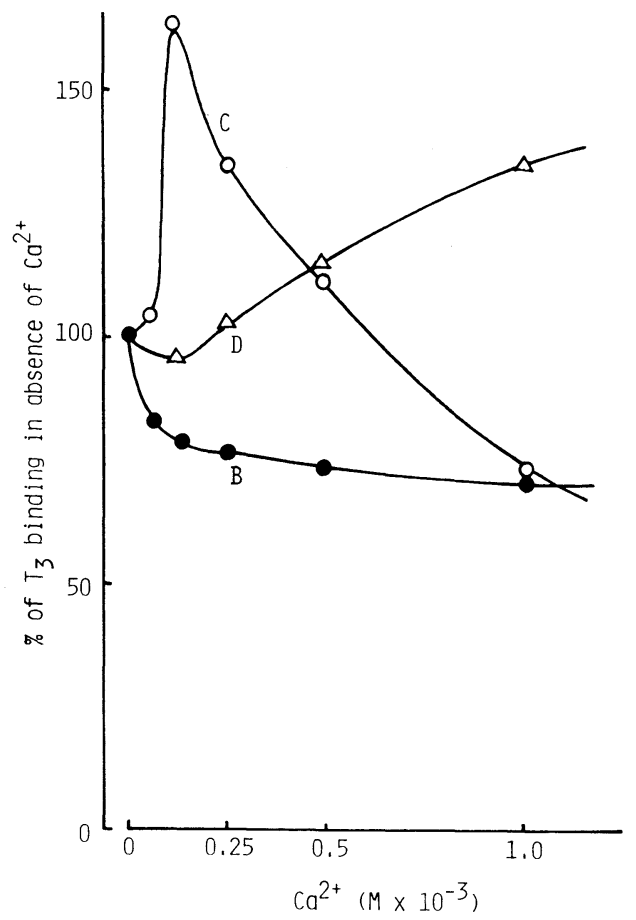

Fig. 4. Effect of $\mathrm{Ca}^{2+}$ on $\mathrm{T}_{3}$ binding to solubilized $\mathrm{T}_{3}$ receptors.

Solubilized $\mathrm{T}_{3}$ receptor fractions were obtained from the experiment shown in Fig. 3. Fraction B, C and D were studied. Binding reactions contained various concentrations of $\mathrm{Ca}^{2+}$ and solubilized protein $(16 \mu \mathrm{g} /$ tube). The specific binding of $T_{3}$ is shown. Each value is the mean of triplicate determinations. chondrial membranes without any change in the association constant after pretreatment of the membranes with $\mathrm{Ca}^{2+}$ (Fig. 7). In studies with gel filtration on a Sephadex $\mathrm{G}-100$ column, three main $\mathrm{T}_{3}$ binding activities were isolated in the supernatant of the incubation mixture (Fig. 8). Pretreatment of outer mitochondrial membranes with $\mathrm{Mg}^{2+}$ or $\mathrm{Mn}^{2+}$ did not produce any soluble binding activity for $\mathrm{T}_{3}$.

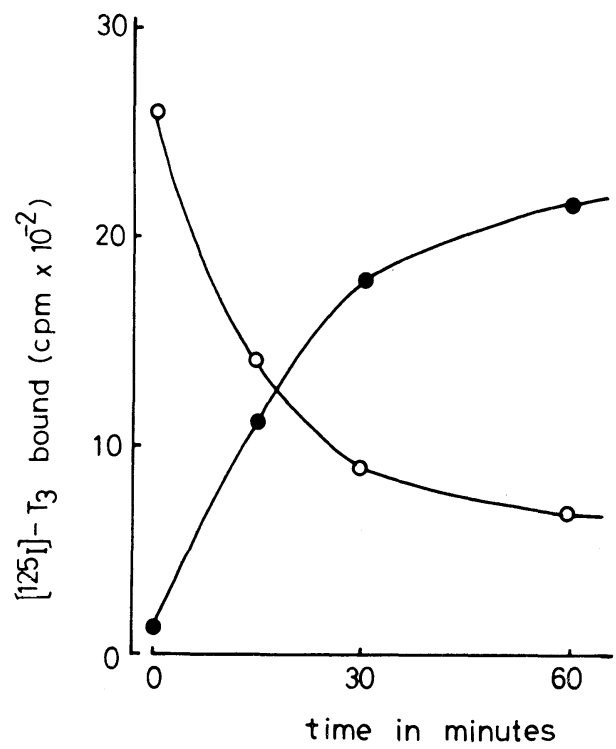

Fig. 5. Effect of pretreatment of outer mitochondrial membranes with $\mathrm{Ca}^{2+}$ on the release of $T_{3}$ receptors.

Outer mitochondrial membranes $(7.5 \mathrm{mg}$ protein) were incubated in the presence of $1 \mathrm{mM} \mathrm{Ca}^{2+}$ at $34^{\circ} \mathrm{C}$ for appropriate incubation time. After the incubation, the mixture was centrifuged at $105,000 \times g$ for $1 \mathrm{hr}$ at $0^{\circ} \mathrm{C}$. The pellet was resuspended with the same volume of $\mathrm{Ca}^{2+}$-omitted buffer containing $1 \mathrm{mM}$ EGTA, and was used as a residual membrane fraction. After dialysis of both the residual membrane fraction and supernatant against $\mathrm{Ca}^{2+}$-omitted buffer containing $1 \mathrm{~m}$ EGAT, $\left[{ }^{125} \mathrm{I}\right]-\mathrm{T}_{3}$ binding activity in both the fractions was determined. The reaction was performed by adding $100 \mu \mathrm{l}$ of aliquotes of either membrane fraction (- - -) or soluble fraction (- - Each value is the mean of triplicate determinations. 

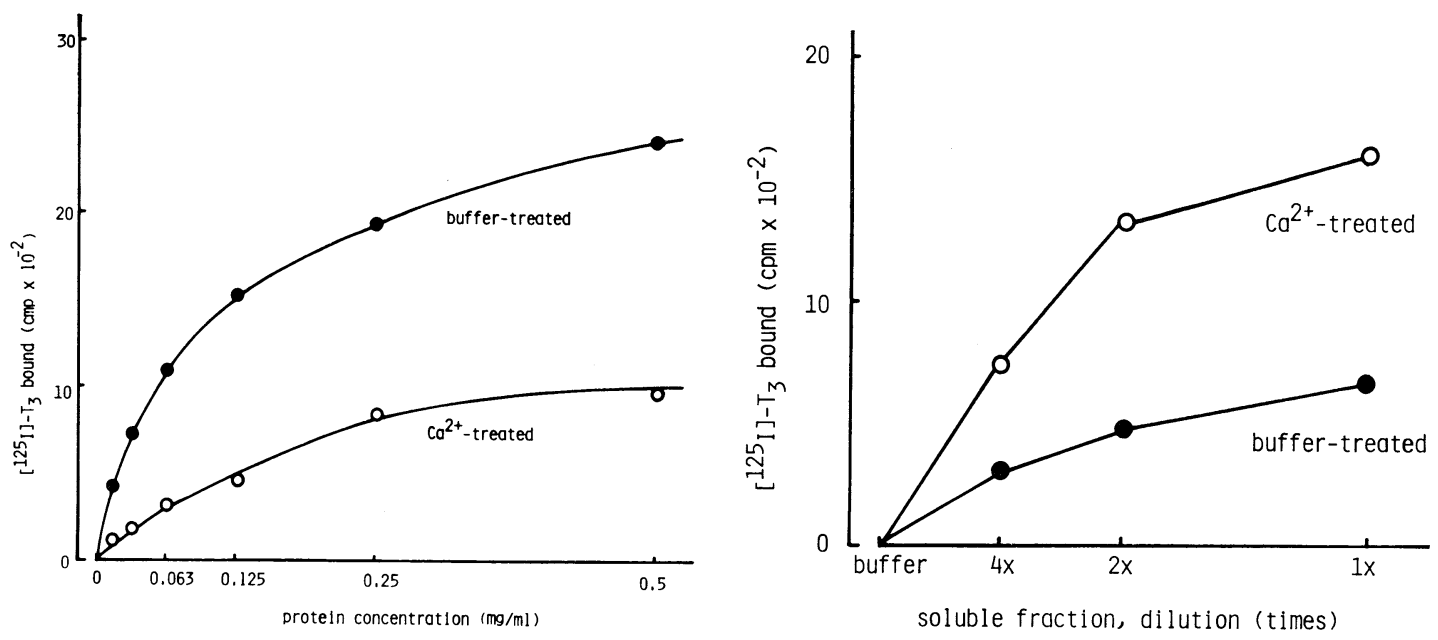

Fig. 6. Effect of pretreatment of outer mitochondrial membranes with $\mathrm{Ca}^{2+}$ on the release of $\mathrm{T}_{3}$ receptors.

Outer mitochondrial membranes $(7.5 \mathrm{mg}$ protein) were incubated in the presence or absence of $1 \mathrm{mM} \mathrm{Ca}^{2+}$ for $1 \mathrm{hr}$ at $34^{\circ} \mathrm{C}$. In control group, $1 \mathrm{mM}$ EGTA was added to $\mathrm{Ca}^{2+}$-omitted medium. After the incubation, the soluble and residual membrane fractions were separated by centrifugation at $105,000 \times g$ for $1 \mathrm{hr}$ at $0^{\circ} \mathrm{C}$. Binding activity in the residual membrane fraction (left panel) and in the soluble fraction (right panel) was determined after dialysis of these fractions against $\mathrm{Ca}^{2+}$-omitted buffer containing $1 \mathrm{mM}$ EGTA. Buffer-treated indicates the control group. Each value is the mean of duplicate determinations.

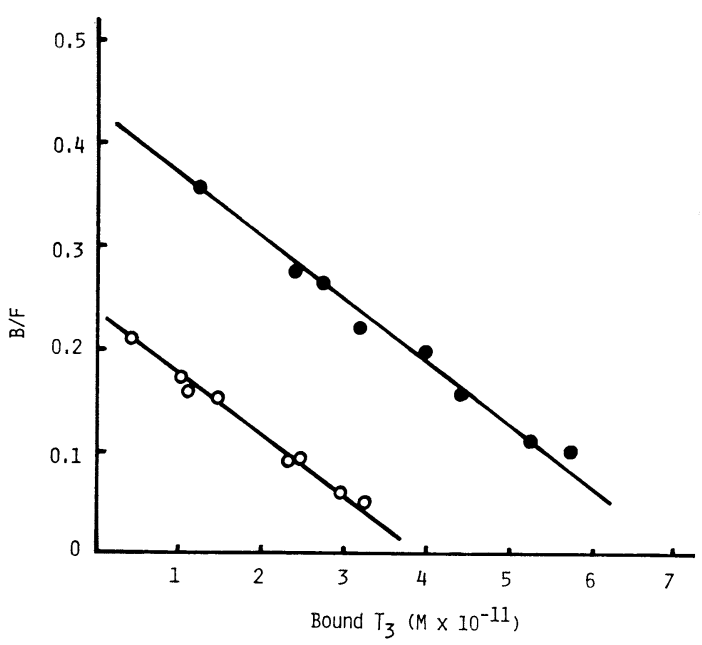

Fig. 7. Scatchard analyses of the binding of $\left[{ }^{125} \mathrm{I}\right]-\mathrm{T}_{3}$ by buffer-treated $(-\mathbf{-}-)$ and by $\mathrm{Ca}^{2+}$-treated (-O-) outer mitochondrial membranes. Both the membrane fractions were prepared as described in Fig. 6. The $\mathrm{T}_{3}$ binding assay was performed as mentioned in Materials and Methods. Each membrane fraction (50 $\mu \mathrm{g}$ of protein) was incubated with various concentrations of $\left[{ }^{125} \mathrm{I}\right]-\mathrm{T}_{3}$ in the presence or absence of unlabeled $\mathrm{T}_{3}\left(10^{-6} \mathrm{M}\right)$ for $1 \mathrm{hr}$ at $30^{\circ} \mathrm{C}$. The specific binding of $\left[{ }^{125} \mathrm{I}\right]-\mathrm{T}_{3}$ was determined. Each value is the mean of triplicate determinations. 


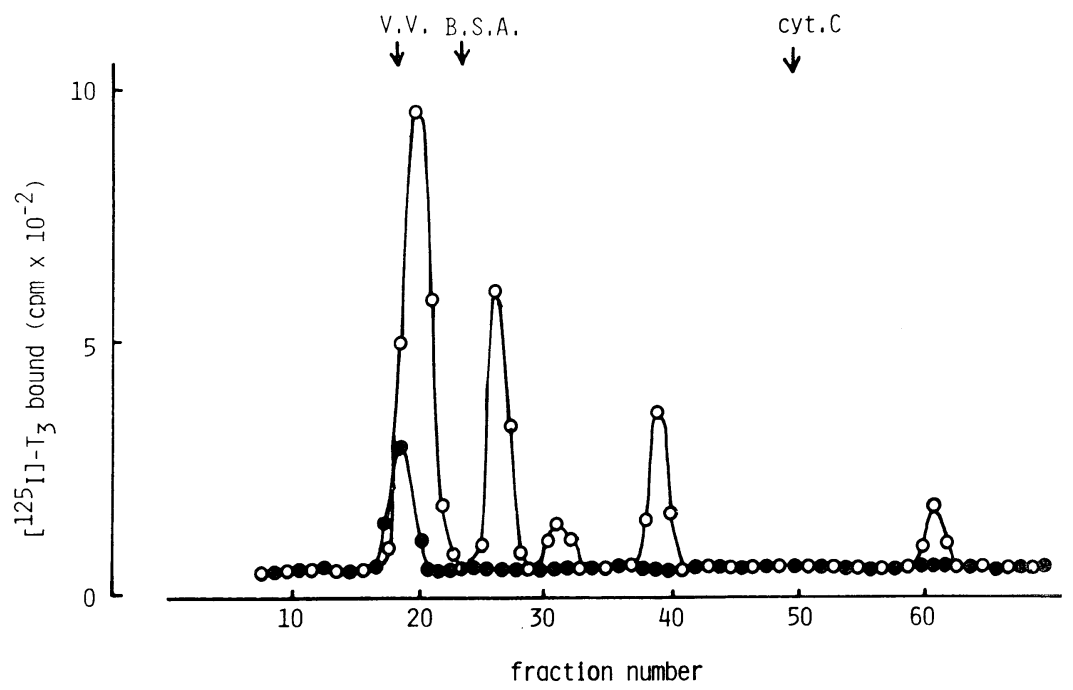

Fig. 8. Gel filtration profile of soluble $\mathrm{T}_{3}$ receptors.

The soluble fractions were prepared by pretreatment of outer mitochondrial membranes with $\mathrm{Ca}^{2+}$ containing buffer or $\mathrm{Ca}^{2+}$-omitted buffer as described in Fig. 6. Soluble fractions were applied to a Sephadex G-100 column and the receptors were eluted with the buffer which did not contain $\mathrm{Ca}^{2+}$. The $\mathrm{T}_{3}$ binding activity in each fraction was assayed in the presence or absence of unlabeled $\mathrm{T}_{3}\left(10^{-6} \mathrm{M}\right)$. The specific binding is shown. - - - binding activity in soluble fraction obtained from the control group which was prepared by treatment of the membrane with buffer containing 1 mM EGTA. - $\bigcirc-$; binding activity in soluble fraction obtained from $\mathrm{Ca}^{2+}$-treated outer mitochondrial membranes. Soluble fraction obtained from $\mathrm{Mg}^{2+}$ - or $\mathrm{Mn}^{2+}$-treated membranes gave a similar result to that of the control group. The elution positions of BSA and cytochrome $c$ (Cyt. C) are Shown. V.V. indicates the position of the void volume of the column.

\section{Discussion}

In the present study we have demonstrated that calcium ion plays an important role in the regulation of binding of $\mathrm{T}_{3}$ to outer mitochondrial membranes. The mechanism of this regulation is an inhibition of calcium on $\mathrm{T}_{3}$ binding to the membranes. We also demonstrated that the inhibitory effect of calcium ion is mediated by the release of $\mathrm{T}_{3}$ receptors from outer mitochondrial membranes.

It is known that $\mathrm{Ca}^{2+}$ is released from mitochondria by thyroid hormones (Harris, 1979, Shears and Bronk, 1981). The increase in the calcium concentration in the extramitochondrial space may stimulate certain reactions which require $\mathrm{Ca}^{2+}$. A thyroid hormone-induced increase in the calcium concentration in this space may regulate thyroid hormone action at sites subsequent to $\mathrm{T}_{3}$ binding to outer mitochondrial membranes. As is shown in the present study, calcium ion strongly inhibited $\mathrm{T}_{3}$ binding to outer mitochondrial membranes, suggesting that calcium ion, which is released from mitochondria by thyroid hormone stimulation, plays a role in the regulation of $\mathrm{T}_{3}$ binding to the membranes. Possibly this mechanism is a feedback regulation of thyroid hormone action in the intracellular space. Other divalent cations also inhibited $\mathrm{T}_{3}$ binding in higher concentrations, but not 
in their physiological concentrations, suggesting that calcium ion is a specific regulator for $\mathrm{T}_{3}$ binding.

$\mathrm{Ca}^{2+}$ did not inhibit $\mathrm{T}_{3}$ binding to soluble $\mathrm{T}_{3}$ receptors derived from outer mitochondrial membranes, suggesting that calcium ion does not interact directly with $\mathrm{T}_{3}$ receptor molecules. However, we obtained results which indicate $\mathrm{Ca}^{2+}$ enhances $\mathrm{T}_{3}$ binding to the isolated soluble $T_{3}$ receptors. We cannot explain whether or not these enhancements are physiological.

The decrease in the number of $T_{3}$ binding sites in outer mitochondrial membranes and the appearance of soluble $\mathrm{T}_{3}$ binding activities in the supernatant after treatment of the membranes with $\mathrm{Ca}^{2+}$, indicated that $\mathrm{Ca}^{2+}$ inhibition of $\mathrm{T}_{3}$ binding to the membranes occurs through the release of $T_{3}$ receptors from outer mitochondrial membranes. Recently, calcium-activated proteinases in several tissues have been isolated (Guroff, 1964, Murachi et al., 1980, Murachi et al., 1981). Although it is not known whether $\mathrm{Ca}^{2+}$-activated proteinases interact with outer mitochondrial membranes, it is possible that a thyroid hormone-induced increase in calcium concentration in the extramitochondrial space activates these proteinases and that results in structural changes in the outer mitochondrial membranes or degradation of some molecules, including $\mathrm{T}_{3}$ receptors, in the membranes.

In the gel filtration study, we obtained different $T_{3}$ binding activity profiles in soluble fraction for Triton $\mathrm{X}-100$ and $\mathrm{Ca}^{2+}$. treated. Probably these treatments produce different molecular sized soluble $\mathrm{T}_{3}$ receptors. Furthermore, although $\mathrm{T}_{3}$ binding to isolated Triton $\mathrm{X}-100-$-solubllized- $\mathrm{T}_{3}$ receptors was modified by $\mathrm{Ca}^{2+}$, that to the isolated receptors released by $\mathrm{Ca}^{2+}$ was not affected by $\mathrm{Ca}^{2+}$ (Data not shown). These results suggest that not only the size of $T_{3}$ receptors but also $T_{3}$ binding characteristics of $T_{3}$ receptors released by $\mathrm{Ca}^{2+}$ are different from those solubilized by Triton $\mathrm{X}-100$.
Several workers could not detect the thyroid hormone receptors in outer mitochondrial membranes (Sterling and Milch, 1975, Tata et al., $1962 a$ and b). Since calcium ion can release $\mathrm{T}_{3}$ receptors from outer mitochondrial membranes, it might be easy to lose the receptors from the membranes in the presence of calcium ion. In our experiments $1 \mathrm{mM}$ EGTA was employed during preparation of membranes, and we could detect $T_{3}$ receptors in the MAOenriched fraction which is considered to be the outer mitochondrial membrane fraction.

In this report we did not use the agents which inhibit calcium efflux from mitochondria. And it is necessary to study the effect of these agants on $T_{3}$ binding to mitochondria. While the role of calcium ion in $\mathrm{T}_{3}$ binding to outer mitochondrial membrane is no doubt important, the relationship between $\mathrm{Ca}^{2+}$, which is released from mitochondria by thyroid hormone, and $\mathrm{T}_{3}$ binding to the membrane remains to be elucidated.

\section{References}

Carafoli E., and M. Cromton (1978). The regulation of intracellular calcium by mitochondria. Annals of the New York Academy of Science. 307, 269-284.

Comte J. and D. C. Gautheron (1979). Preparation of outer membrane from pig heart mitochondria. in Methods in Enzymology Vol. LV, Biomembrane part F. Bioenergetics (Fleisher S., Packer L. edited) Academic Press, New York pp. $98-104$.

Guroff G. (1964). A neutral, calcium-activated proteinase from the soluble fraction of rat brain. J. Biol. Chem. 239, 149-155.

Harris E. J. (1979). Stimulation of mitochondrial calcium ion efflux by thiol-specific reagents and by thyroxine. The relationship to adenine diphosphate retention and to mitochondrial permeability. Biochim. Biophys. Acta. 451, 92-95.

Hashizume K. and K. Ichikawa (1982). Localization of $3,5,3^{\prime}-\mathrm{L}$-triiodothyronine receptor in 
rat kidney mitochondrial membranes. Biochem.

Biophys. Res. Commun. 106, 920-926.

Hullert A. J., M. L. Augee and J. K. Raison (1976). The influence of thyroid hormone on the structure and function of mitochondrial membranes. Biochim. Biophys. Acta. 455, 597601.

Ichikawa K., K. Hashizume and T. Yamada (1982). Monoamine oxidase inhibitory modulators in rat heart cytosol: Evidence for induction by thyroid hormone. Endocrinol. 111, 1803-1809.

Lowry O. H., N. J. Rosebrough, A. L. Farr and R. J. Randall (1951). Protein measurement with Folin phenol reagent. J. Biol. Chem. 193, 265-275.

Mela L. and S. Seits (1979). Isolation of mitochondria with emphasis heart mitochondria from small amounts tissue. in Methods in Enzymology, Vol. LV, Biomembrane part F. Bioenergetics; (Fleisher S. and Packer L. edited) Academic Press, New York, pp 39-46.

Murachi, T., I. Nishiura, K. Tanaka, T. Murakami, M. Hatanaka and T. Inamoto (1980). Intracellular $\mathrm{Ca}^{2+}$-dependent protease and its inhibitor. in Frontiers in Protein Chemistry (Liu T.-Y., Mamiya G. and Yasunobu K., edited) Elsevier North-Holland, New York, pp 343-357.

Murachi T., K. Tanaka, M. Hatanaka and T. Murakami (1981). Intracellular $\mathrm{Ca}^{2+}$-dependent protease (Calpain) and its high-endogenous inhibitor (Calpastatin). Adv. Enzyme Reg. 19,
407-424.

Rasmussen H. and M. C. Gustin (1978). Some aspects of the hormonal control of cellular calcium metabolism. Annals of the New York Academy Science. 307, 391-401.

Shears S. B. and J. R. Bronk (1981). The effects of thyroxine treatment, in vivo and in vitro, on $\mathrm{Ca}^{2+}$ efflux from rat liver mitochondria. FEBS letters 126, 9-13.

Statav J. R., S. S. Katyare, P. Fatterpaker and A. Sreenivasa (1976). Regulation of mitochondrial membrane protein turnover by thyroid hormone(s). Biochim. Biophys. Acta. 451, 92-95.

Sterling K. and P. O. Milch (1975). Thyroid hormone binding by a compartment of mitochondrial membrane. Proc. Natl. Acad. Sci. U.S.A. 72, 3225-3228.

Tata J. R., L. Ernster and E. M. Suranyi (1962). Interaction between thyroid hormone and cellular constituents. I. Binding to isolated subcellular particles and sub-particulate fractions. Biochim. Biophys. Acta. 60, 461-479.

Tata J. R., L. Ernster and E. M. Suranyi (1962). Interaction between thyroid hormone and cellular constituents. II. Intracellular distribution and the cell-sap effect. Biochim. Biophys. Acta. 60, 480-491.

Wurtman R. J. and J. Axelrod (1963). A sensitive and specific assay for the estimation of monoamine oxidase. Biochem. Pharmacol. 12, 1439-1441. 